\begin{tabular}{|c|c|c|c|c|c|c|}
\hline \multirow{4}{*}{ Impact Factor: } & ISRA (India) & $=3.117$ & SIS (USA) & $=0.912$ & ICV (Poland) & $=6.630$ \\
\hline & ISI (Dubai, UAE & $=0.829$ & РИНЦ (Russia & $=0.156$ & PIF (India) & $=1.940$ \\
\hline & GIF (Australia) & $=0.564$ & ESJI (KZ) & $=8.716$ & IBI (India) & $=4.260$ \\
\hline & JIF & $=1.500$ & SJIF (Morocco & $=\mathbf{5 . 6 6 7}$ & OAJI (USA) & $=0.350$ \\
\hline
\end{tabular}

\section{SOI: $1.1 /$ TAS $\quad$ DOI: $10.15863 /$ TAS \\ International Scientific Journal Theoretical \& Applied Science}

\author{
p-ISSN: 2308-4944 (print) e-ISSN: 2409-0085 (online) \\ Year: $2019 \quad$ Issue: $04 \quad$ Volume: 72 \\ Published: $30.04 .2019 \quad$ http://T-Science.org
}

\section{UDC 004.386}

QR - Issue

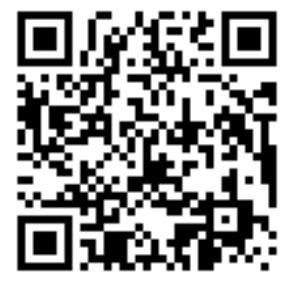

QR - Article

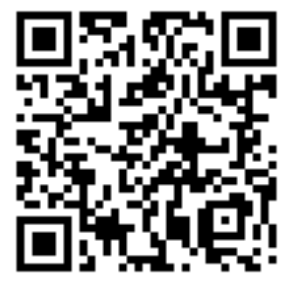

A. B. Karshiev

head of the department "Software Engineering" docent,

Samarkand branch of

the Tashkent University of Information Technologies named after Muhammad Al Khorezmiy

S.S. Nabiyeva master student,

the Tashkent University of Information Technologies named after Muhammad Al Khorezmiy,

A.Sh. Egamkulov

master student,

the Tashkent University of Information Technologies named after Muhammad Al Khorezmiy,

Republic of Uzbekistan, Samarkand

\title{
MEDICAL INFORMATION SYSTEMS
}

Abstract: The article addresses the issues of the concept of information technology, their current capabilities. The effectiveness of the implementation of information systems of various functionalities for medical institutions (MCI). The use of modern communications and local information networks in medicine. The study of the levels of MIS, their classification and prospects for implementation.

Key words: MIS, MCI, information technology, classification, local network, database.

Language: English

Citation: Karshiev, A. B., Nabiyeva, S. S., \& Egamkulov, A. S. (2019). Medical information systems. ISJ Theoretical \& Applied Science, 04 (72), 505-508.

Soi: http://s-o-i.org/1.1/TAS-04-72-64 Doi: crossef https://dx.doi.org/10.15863/TAS.2019.04.72.64

\section{Introduction}

Modern medical organizations produce and accumulate huge amounts of data. The quality of medical care, the general standard of living of the population, the level of development of the country as a whole and of each of its territorial entities in particular depends on how effectively this information is used by doctors, managers, and governing bodies. Therefore, the need to use large, and at the same time still constantly growing, amounts of information in solving diagnostic, therapeutic, statistical, managerial and other tasks, determines today the creation of information systems in medical institutions.

Maps, bulletins, procedural reports, records of patients, drugs - all the workflow was done on paper. This affected the speed and, consequently, the quality of patient care, hampered the work of medical, medical personnel, which led to medical errors, a great investment of time to fill out cards, and to compile reports. This complicated the management of health facilities MCI (lack of control over the work of the units, lack of operational, analytical information) and the work of the controlling authorities.

A feature of the MIS is the transition from local work with medical information to an integrated system, where all data passing through the institution is accessible from a single information environment. At the same time, the paperless technology is fully implemented, however, the possibility of obtaining a "hard copy" of any document remains. The use of modern medical technologies allows to improve the quality of medical services, optimize the management of various structural medical units and create the basis for reaching the world level of medical services.

Information technology in medicine

Information technology (IT) is an ordered set of methods and methods for collecting, processing, 


\begin{tabular}{|c|c|c|c|c|c|c|}
\hline \multirow{4}{*}{ Impact Factor: } & ISRA (India) & $=3.117$ & SIS (USA) & $=0.912$ & ICV (Poland) & $=6.630$ \\
\hline & ISI (Dubai, UAE & $=0.829$ & РИНЦ (Russia) & $=0.156$ & PIF (India) & $=1.940$ \\
\hline & GIF (Australia) & $=0.564$ & ESJI (KZ) & $=8.716$ & IBI (India) & $=4.260$ \\
\hline & JIF & $=1.500$ & SJIF (Morocco & $=5.667$ & OAJI (USA) & $=0.350$ \\
\hline
\end{tabular}

accumulating, storing, searching for distribution, protection and consumption of information carried out in the course of management activities.

Modern IT is widely used computers, computer networks and all kinds of software in the management process. The purpose of the introduction of information technology is the creation of information systems (IS) for the analysis and adoption of management decisions based on them. Information technology includes two factors: machine and human. A specific embodiment of information technology is mainly automated systems, and only in this case it is customary to talk about computer technology. For modern information technology, the following features are typical:

- end-to-end information support at all stages of information transmission on the basis of integrated databases providing for a unified unified form of data presentation, storage, search, display, recovery and protection;

- paperless processing of documents;

- collaboration opportunities based on network technology, integrated by means of communication;

- the possibility of adaptive restructuring of forms and ways of presenting information in the process of solving a problem.

The effectiveness of management depends not only on the available resources, but also on a clearly formulated realistic attainable goal, the results of which are evaluated by appropriate indicators. Without this, the control system is not effective. The main purpose of these processes is to create a single information space for all stakeholders (potential information users): various health structures and services, management and control authorities, manufacturers of medical equipment and medicines, research organizations, and consumers of medical goods and services. This will significantly intensify the exchange of information and the speed of implementation in daily practice of the latest achievements of science and practice that meet the objectives of improving and developing health care.

New information technologies can significantly improve management efficiency and solve complex health problems through prompt access to specialized databases.

Medical information systems and local information networks

The development of information technologies and modern communications, the emergence in clinics of a large number of automated medical devices, tracking systems and individual computers led to a new round of interest and to a significant increase in the number of medical information systems (MIS) clinics, moreover, as in large medical centers with large information flows and in mediumsized medical centers and even in small clinics or clinical departments.
The modern concept of information systems involves the integration of electronic patient records (electronic patient records) with medical image archives and financial information, monitoring data from medical devices, the results of automated laboratories and tracking systems, the availability of modern means of information exchange (electronic hospital mail, Internet, video conferencing etc.).

Thus, the medical information system (MIS) is a combination of software and hardware, databases and knowledge designed to automate various processes occurring in hospitals and the health care system (MCI).

The objectives of creating an MIS are:

1. Creating a single information space;

2. Monitoring and management of the quality of care;

3. Increasing the transparency of medical institutions and the effectiveness of management decisions;

4. Analysis of the economic aspects of medical care;

5. Reducing the time of examination and treatment of patients;

6. The introduction of an MIS has a positive effect on all participants in the health care system.

MIS levels

According to the staff of the American Institute of Medical Records (Medical Records Institute, USA), in fact, there are 5 different levels of computerization for the MIS.

The FIRST level of an MIS is automated medical records. This level is characterized by the fact that only about $50 \%$ of the information about the patient is entered into the computer system, and in various forms is given to its users in the form of reports. In other words, such a computer system is a kind of automated environment around the "paper" technology of patient management. Such automated systems usually cover patient registration, discharge, hospital transfers, entering diagnostic information, appointments, conducting transactions, financial issues, go along with the "paperwork" and serve primarily for different types of reporting.

The SECOND level of the MIS is the Computerized Medical Record System. At this level of development of the MIS, those medical documents that were not previously entered into electronic memory (first of all, we are talking about information from diagnostic devices, obtained in the form of various printouts, scans, topograms, etc.), are indexed, scanned and stored in electronic image storage (usually on magneto-optical drives). The successful implementation of such MIS began practically only in 1993.

The THIRD level of development of the MIS is the introduction of electronic medical records (Electronic Medical Records). In this case, an appropriate infrastructure should be developed in the 


\begin{tabular}{|c|c|c|c|c|c|c|}
\hline \multirow{4}{*}{ Impact Factor: } & ISRA (India) & $=3.117$ & SIS (USA) & $=0.912$ & ICV (Poland) & $=6.630$ \\
\hline & ISI (Dubai, UAE & $=0.829$ & РИНЦ (Russia & $=0.156$ & PIF (India) & $=1.940$ \\
\hline & GIF (Australia) & $=0.564$ & ESJI (KZ) & $=8.716$ & IBI (India) & $=4.260$ \\
\hline & JIF & $=1.500$ & SJIF (Morocco & $=5.667$ & OAJI (USA) & $=0.350$ \\
\hline
\end{tabular}

medical institution for entering, processing and storing information from their workplaces. Users must be identified by the system, they are given access rights corresponding to their status. The structure of electronic medical records is determined by computer processing capabilities. At the third level of development of an MIS, an electronic medical record may already play an active role in the decision-making process and integration with expert systems, for example, when making a diagnosis, choosing medicines, taking into account the patient's current somatic and allergic status, etc.

At the FOURTH level of development of the MIS, which the authors called the systems of electronic medical records (Electronic Patient Record Systems or other sources of Computer-based Patient Record Systems), patient records have much more information sources. They contain all the relevant medical information about a particular patient, the sources of which can be one or several medical institutions. For such a level of development, a national or international patient identification system, a unified system of terminology, information structure, coding, etc., are necessary.

The FIFTH level of development of an MIS is the Electronic Health Record. It differs from the electronic patient record system by the existence of virtually unlimited sources of information about the patient's health. Information comes from areas of alternative medicine, behavioral activities (smoking, playing sports, using diets, etc.).

At the same time, existing and projected MIS mainly perform separate functions of an information system from a number of workstations to assist in organizing information services to the accounting information system of a medical institution or major health-related processes (for example, information support for postoperative patients or maintaining medical statistics).

The specificity of medical information systems is as follows:

1. Patient orientation: the core of the MIS is the patient record.

2. Increased developer responsibility.

3. Integration of administrative, medical and financial information.

4. Integration with specific types of equipment.

Medical information systems are classified by the direction of the medical institution:

- MIS for hospitals

- MIS for polyclinics and ambulance stations

- MIS for dental clinics

- MIS for sanatoriums (medical institutions)

Medical information systems have a number of functional capabilities:
Collection, registration, structuring and creation of information space;

- Ensuring the exchange of information;

- Storage and retrieval of information;

- Statistical data analysis;

- Monitoring the effectiveness and quality of medical care;

- Decision support;

- Analysis and control of institutions, resource management institutions;

- Support of the economic component of the treatment process;

- Training staff;

Let us consider in more detail the basic functions of an MIS.

As in any IS, these include the collection of information, which is preceded by obtaining primary patient data as a result of his examination or automatically using special equipment for recording the patient's condition (basically such information can be considered technological), and, finally, from other specialized MIS (for example, pharmacopoeia, anesthesiology or from medical libraries). Of course, in such a system, information needs to be structured and stored, as well as search tools not only in the database, but also in various storages, in particular, roentgenograms or cardiograms. The large volumes of computations associated with the quantitative evaluation of information in the system require the inclusion of various applications in the MIS. Modern MIS work on the network, so when they operate, users can have access to distributed databases or other diverse information resources, including those located on the Internet. A significant expansion of the range of equipment used in health care, and an increase in the quality of medical care, lead to the inclusion of additional information in the MIS resource. In this way, in modern MIS, an increase in the resource is largely due to technological information. It has now become quite possible to include, for example, at the hospital level, information about drugs procured through pharmacies. So, we can assume that now the MIS can arbitrarily fully support the functions of any medical institution. Currently, MIS are based on any computers, including PDA, scanners, from tablet to tomographs, and special devices for biometric observations, digital and analog storage of information, video and photography, sound recording and playback. Moreover, thanks to network technologies, integrated MIS can have a heterogeneous architecture. MIS storage facilities allow you to work with virtually unlimited amounts of information located in local and regional networks, as well as on the Internet.

System organization of information storage is supported by DBMS, which are selected both as part of client-server technology and as a traditional database for an individual PC. 


\begin{tabular}{|c|c|c|c|c|c|c|}
\hline \multirow{4}{*}{ Impact Factor: } & ISRA (India) & $=3.117$ & SIS (USA) & $=0.912$ & ICV (Poland) & $=6.630$ \\
\hline & ISI (Dubai, UAE & $=0.829$ & РИНЦ (Russia & $=\mathbf{0 . 1 5 6}$ & PIF (India) & $=1.940$ \\
\hline & GIF (Australia) & $=0.564$ & ESJI (KZ) & $=8.716$ & IBI (India) & $=4.260$ \\
\hline & JIF & $=1.500$ & SJIF (Morocco & $=5.667$ & OAJI (USA) & $=0.350$ \\
\hline
\end{tabular}

\section{Ways of development of medical information technology \\ Medical information technologies include} means of influencing the organism by external informational factors, a description of the methods and methods of their use, and the process of learning practical skills. Accordingly, the further development of these technologies requires consideration and solution of the following practical issues. In the first place is the urgent question of the need for widespread introduction into clinical practice of approved means and methods of informational impact that meet such requirements as safety and ease of their use, high therapeutic efficacy of their use. The next topical issue is the promotion and encouragement of the development and creation of new means and methods of influencing the human body in accordance with the principles and postulates of information medicine. Further development and improvement of this field of medicine is associated with the optimization of means and methods of biofeedback with informational effects adequate to changes in the body in accordance with the principles and postulates of information medicine. One of the main ways to solve a number of medical, social and economic problems is currently the informatization of the work of medical personnel. These problems include the search for effective tools that can improve the three most important indicators of health care: the quality of treatment, the level of patient safety, and the cost-effectiveness of medical care. The basic element of informatization is the use of modern clinical information systems in hospitals, equipped with decision support mechanisms. However, these systems are not widely used, since scientific and methodological approaches to the creation of clinical information systems have not yet been developed.

\section{Conclusion}

Information technologies can be successfully applied in various fields of modern medicine. For example, in the field of patient safety, modern automated systems can enhance the quality and safety control of medicines and medical services, reduce the likelihood of medical errors, provide ambulance with the means of rapid communication and access to vital patient information. Modern technological solutions are able to provide free access to health services regardless of the place of residence of the patient, significantly increase the availability of high-tech medical services, medical expertise.

Thus, we can safely say that medical information systems, consisting of many specialized modules, help in the simultaneous solution of diagnostic, therapeutic, managerial, financial, statistical and other tasks. In turn, all this, ultimately, contributes to the achievement of the final goal of any health care facility (MCI) - the provision of quality medical services.

\section{References:}

1. Nazarenko, G. I., Guliev, Y. I., \& Ermakov, D. E. (2005). Medical information systems: theory and practice. (p.320). Moscow: Fizmatlit.

2. Vyalkov, A. I. (2009). Management and economics of health care. Moscow: GEOTARMedia.

3. Krenke, D. (2003). Theory and practice of building databases. (p.800). SPb: Peter.

5. Starinsky, V. V., \& Gretsova, O. P. (n.d.). Information Technologies in Oncology - FSI "Moscow P.A. Herzen Rosmedtechnoliy »"

6. Homonenko, A. D. (2006). Databases: a textbook for higher educational institutions. (p.736). Moscow: Binom-Press.

7. (2016). Textbook on medical informatics: S.A. Feylamazov. Information technologies in medicine: A manual for medical colleges. (p.163). Makhachkala: DBMK.

8. (2005, April 5). Integration of the healthcare enterprise (IHE). Available at http://www.ihe.net/

9. (2005, April 5). Digital image and communication in medicine. Available at http://medical.nema.org/

10. (2005, April 5). Integration of the health care enterprise (IHE). Available at http://www.ihe.net/

11. Gusev, A. V., Romanov, F. A., \& Dudanov, I. P. (2001). Experience in developing a medical information system. Medical Academic Journal, №1, p. 18. 